\title{
Genetic Diversity Analysis in Multihead Inbred Lines of Sunflower (Helianthus annuus L.)
}

\author{
G.H. Naik* , M.K. Ghodke and T.A. Chavan
}

Department of Genetics and Plant Breeding, College of Agriculture, Latur-413 512, Vasantrao Naik Marathwada Agricultural University, Parbhani, Maharashtra, India

*Corresponding author

\section{A B S T R A C T}

\section{Keywords}

$\mathrm{D}^{2}$ statistics, Sunflower, Genetic divergence

Article Info

Accepted:

04 September 2018 Available Online: 10 October 2018
Sixty-one sunflower (Helianthus annuus L.) multihead inbred lines including one check were evaluated to study the morphological variations for twelve characters by using Mahalanobis $\mathrm{D}^{2}$ statistics. These genotypes were grouped into 7 clusters, among which the cluster I with 52 genotypes was the largest followed by cluster II with 4 genotypes. Maximum inter cluster distance was recorded between cluster II and VII (740.36) followed by clusters I and VII (426.99). Hence hybridizing between these divergent groups may lead to higher variation in segregating population. Among 7 clusters, IC-597575, EC601938, EC-640337, IC-438395 and SS-2038 were most divergent lines compared to other and crosses may be affected among the genotypes of these clusters to get more heterosis among the hybrids. The study revealed that the characters viz., Plant height $(\mathrm{cm})$, Oil content $(\%)$, No of branches per plant contributed more to the total genetic divergence in the genotypes.

\section{Introduction}

Sunflower (Helianthus annuus L.) has become an important oil crop in the world. It was taken up in view of its various advantages viz., photo and thermo insensitivity, short duration, high yield and better quality of oil, high oleic acid $(20 \%)$, linoleic acid $(70 \%)$, palmitic acid (4.6\%) and stearic acid (2.3\%). In India Sunflower is grown over an area of 3.44 lakh ha with a production of 2.41 lakh tonnes during 2016-2017 with an average productivity of $699 \mathrm{~kg} / \mathrm{ha}$. In Maharashtra the crop is grown in area of 25.7 thousand ha with a production of 16.6 thousand tonnes having average productivity of $646 \mathrm{~kg}$ per ha.
(Anonymous, 2017-18). Genetic diversity is one of the criteria of parent selection for hybridization programme. The quantification of genetic diversity through biometrical procedures such as Mahalanobis's D ${ }^{2}$ statistic has made it possible to choose genetically divergent parents. The present study aimed to assess the genetic divergence among 61 multihead inbred lines of sunflower.

\section{Materials and Methods}

The experimental material consisted of 61 sunflower inbred lines including one check (SS-2038) obtained from Oilseeds Research station, Latur. A detail of the inbred lines and 
check varieties sown during kharif 2017 in a randomized block design, with two replications, plot size of $1.20 \mathrm{~m} \mathrm{X} 3.0 \mathrm{~m}$. fertilizer dose given 60:30:30 NPK Kg/ha and spacing maintained $60 \times 30 \mathrm{~cm}$. observations were recorded on 12 morphological traits viz., days to $50 \%$ flowering, days to maturity, plant height $(\mathrm{cm})$, head diameter $(\mathrm{cm})$, no of branches per plant, seed filling percent, hull content percent, 100 seed weight (g), oil content percent, seed yield per plant, volume weight $(\mathrm{g} / \mathrm{ml})$ and pollen production $(\mathrm{mg}) /$ plant. The data were recorded on three randomly selected plants in each entry in each replication. The data were subjected to statistical analysis using Mahalanobis $\mathrm{D}^{2}$ statistic (Mahalanobis, 1936) and Toucher's method as described by Rao (1952) for determining group constellation.

\section{Results and Discussion}

In the present investigation based on the procedure described by Rao (1952). By following Tocher's method (Singh and Chaudhary, 1977), the inbred were then grouped into seven clusters, maximum genotypes (52) were included in cluster I followed by cluster II (04), cluster III, cluster IV, V, VI, VII with single genotype each (Table 1). Neelima et al., (2015) studied 174 genotypes in 13 clusters which indicate prevalence of good extent of diversity in material. The genotypes grouped within a cluster exhibit a narrow range of genetic variability, whereas in different clusters indicate wider variability. The highest inter cluster distance was found between the cluster II and VII (740.36) followed by cluster I and VII (426.99) (Table 2). The closest proximity was found between cluster V and IV (44.09). The intra cluster distance was maximum in cluster I (88.54). Hence, it is suggested that if the diverse accessions from these diverse groups are used in the breeding programme, it is expected to produce a wide range of genetic variability in the population. Neelima et al., (2015) and Sanju et al., (2018) also reported similar finding in sunflower. Based on mean performance of the cluster of twelve characters (Table 3), it was observed that cluster VI, VII, showed early days to 50 per cent flowering (55.5days), cluster VII were earliest to mature (88.0), cluster II had shortest plant height $(113.63 \mathrm{~cm})$, cluster III $(22.0 \mathrm{~cm})$ and VI (21.5), VII $(18.0 \mathrm{~cm})$ had large head diameter. The genotypes in cluster VII (0.0) and VI (1.8) had less no of branches. The cluster VII showed highest cluster mean for seed filling percentage $(77.0 \%), 100$ seed weight $(6.15 \mathrm{~g})$, oil content $(35.95 \%)$, pollen production $(519.5 \mathrm{mg})$. The genotype in cluster VII $(27.5 \%)$ was lowest for the hull content percentage the higher cluster mean for volume weight recorded in cluster III (64.0).

While, the maximum cluster mean for seed yield was recorded by cluster III $(38.50 \mathrm{~cm})$. Clusters mean revealed the differences in value for particular character between the groups indicating importance of particular cluster for choosing desirable parent for hybridization programme. Chandirakala and Manivannan (2014), Anand et al., (2008) and Neelima et al., (2015) found similar results. The characters, which contributed mostly for genetic divergence were plant height $(22.05 \%)$ followed by oil content (20.77\%), no of branches per plant $(19.73 \%)$, days to maturity $(11 \%)$, pollen production per plant $(10.11 \%)$, head diameter (6.67\%), 100 seed weight $(5.68 \%)$, volume weight $(4.54 \%)$, seed yield per plant $(4.21 \%)$, hull content $(3.61 \%)$ seed filling percentage $(1.48 \%)$ and days to $50 \%$ flowering (1.09) (Table 4). The present findings were in agreement with the findings of Loganathan et al., (2006), Anand et al., (2008) Punitha et al., (2010). The inbred lines viz., IC-597575, EC-601938, EC601785, IC-438395 and EC-640337 have been identified as diverse for all traits as compared to the best check SS-2038 (Fig. 1). 
Fig.1 Clustering pattern of 61 genotypes in sunflower by Tocher's method

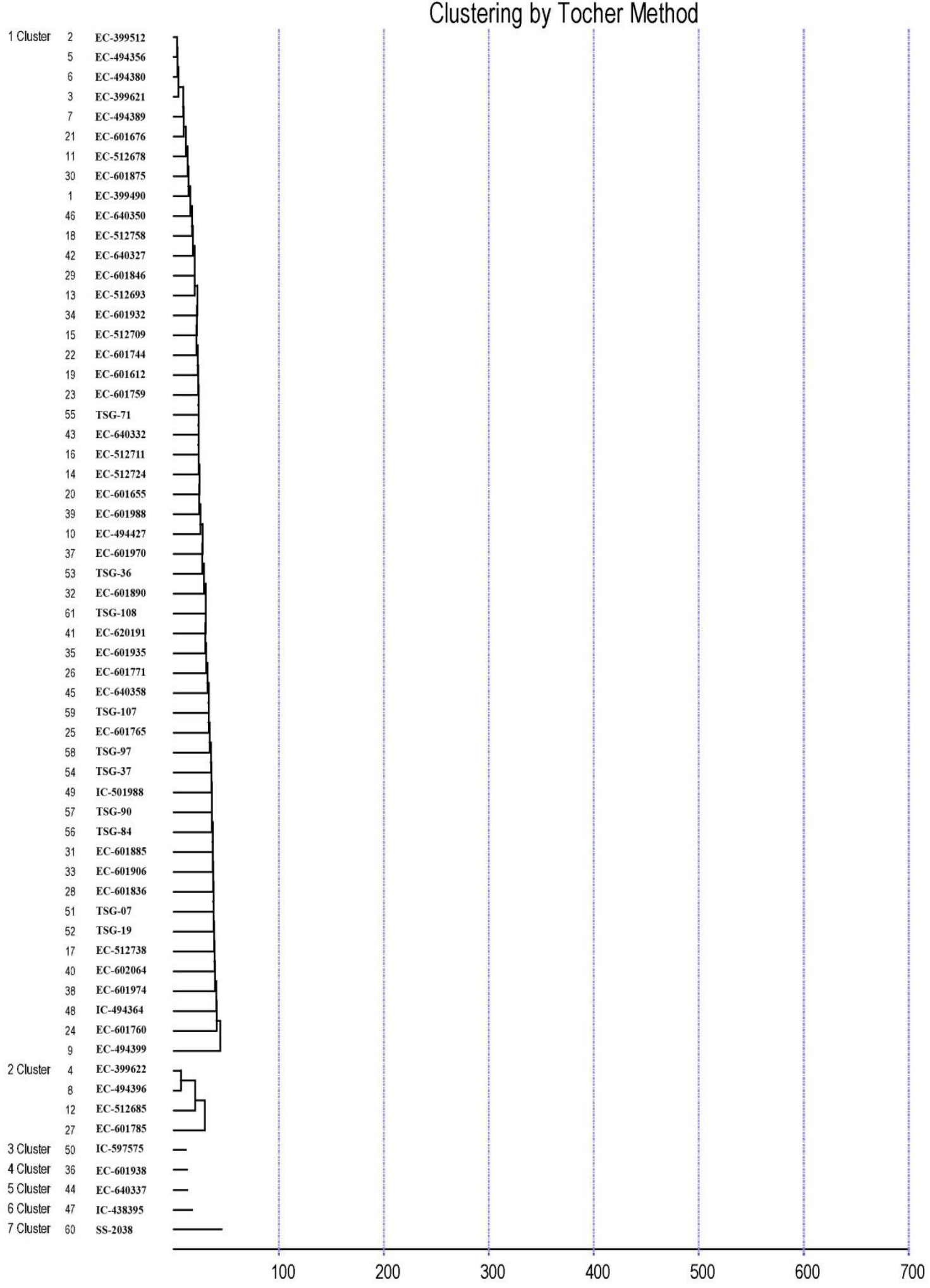


Table.1 Composition of 61 inbred lines including one check of sunflower into different clusters

\begin{tabular}{|c|c|c|c|}
\hline $\begin{array}{l}\text { Sr. } \\
\text { No. }\end{array}$ & Cluster & $\begin{array}{l}\text { No. of inbred } \\
\text { lines }\end{array}$ & Inbred lines \\
\hline 1. & Cluster I & 52 & $\begin{array}{l}\text { EC-399512, EC-494356, EC-494380, EC-399621, EC- } \\
\text { 494389, EC-601676, EC-512678, EC-601875, EC- } \\
\text { 399490, EC-640350, EC-512758, EC-640327, EC- } \\
\text { 601846, EC-512693, EC-601932, EC-512709, EC- } \\
\text { 601744, EC-601612, EC-601759, TSG-71, EC-640332, } \\
\text { EC-512711, EC-512724, EC-601655, EC-601988, } \\
\text { EC494427, EC-601970, TSG-36, EC-601890, TSG- } \\
\text { 108,EC-620191, EC-601935, EC-601771, EC-640358, } \\
\text { TSG-107,EC-601765, TSG-97, TSG-37, IC-501988, } \\
\text { TSG-90, TSG-84, EC-601885, EC-601906, EC-601836, } \\
\text { TSG-07, TSG-19, EC-512738, EC-602064, EC-601973, } \\
\text { IC-494364, EC-601760, EC494399. }\end{array}$ \\
\hline 2. & Cluster II & 4 & EC-399622, EC-494396, EC-512685, EC-601785. \\
\hline 3. & Cluster III & 1 & IC-597575 \\
\hline 4. & Cluster IV & 1 & EC-601938 \\
\hline 5. & Cluster V & 1 & EC-640337 \\
\hline 6. & Cluster VI & 1 & IC-438395 \\
\hline 7. & Cluster VII & 1 & SS-2038 \\
\hline
\end{tabular}

Table.4 Relative contribution of different characters to genetic diversity in sunflower genotypes

\begin{tabular}{|c|l|c|c|}
\hline S. No. & \multicolumn{1}{|c|}{ Character } & Times ranked 1st & $\begin{array}{c}\text { Contribution } \\
(\%)\end{array}$ \\
\hline $\mathbf{1}$ & Days to 50\% flowering & 20 & $1.09 \%$ \\
\hline $\mathbf{2}$ & Days to maturity & 2 & $0.11 \%$ \\
\hline $\mathbf{3}$ & Plant height (cm) & 403 & $22.02 \%$ \\
\hline $\mathbf{4}$ & Head diameter (cm) & 122 & $6.67 \%$ \\
\hline $\mathbf{5}$ & No of branches per plant & 361 & $19.73 \%$ \\
\hline $\mathbf{6}$ & Seed filling (\%) & 27 & $1.48 \%$ \\
\hline $\mathbf{7}$ & Hull content (\%) & 66 & $3.61 \%$ \\
\hline $\mathbf{8}$ & 100 seed weight (g) & 104 & $5.68 \%$ \\
\hline $\mathbf{9}$ & Oil content (\%) & 380 & $20.77 \%$ \\
\hline $\mathbf{1 0}$ & Pollen production (mg)/ plant & 185 & $10.11 \%$ \\
\hline $\mathbf{1 1}$ & Volume weight (g) / plant & 83 & $4.54 \%$ \\
\hline $\mathbf{1 2}$ & Seed yield (g) / plant & 77 & $4.21 \%$ \\
\hline
\end{tabular}


Table.2 Intra and inter cluster distances

\begin{tabular}{|c|c|c|c|c|c|c|c|c|}
\hline Sr. No & Cluster & Cluster I & Cluster II & Cluster III & Cluster IV & Cluster V & Cluster VI & Cluster VII \\
\hline 1. & Cluster I & 88.54 & 144.28 & 125.65 & 134.46 & 126.87 & 149.82 & 426.99 \\
\hline 2. & Cluster II & & 82.69 & 204.76 & 222.02 & 288.69 & 328.03 & 740.36 \\
\hline 3. & Cluster III & & & 0.00 & 153.74 & 143.16 & 82.77 & 274.19 \\
\hline 4. & Cluster IV & & & & 0.00 & 44.09 & 161.94 & 422.47 \\
\hline 5. & Cluster V & & & & & 0.00 & 102.96 & 310.60 \\
\hline 6. & Cluster VI & & & & & & 0.00 & 121.59 \\
\hline 7. & Cluster VII & & & & & & & 0.00 \\
\hline
\end{tabular}

Table.3 Cluster means for 12 characters studied in sunflower

\begin{tabular}{|c|c|c|c|c|c|c|c|c|c|c|c|c|c|}
\hline $\begin{array}{l}\text { Sr } \\
\text { no }\end{array}$ & Cluster & $\begin{array}{l}\text { Days to } \\
50 \% \\
\text { flowering }\end{array}$ & $\begin{array}{l}\text { Days to } \\
\text { maturity }\end{array}$ & $\begin{array}{l}\text { Plant } \\
\text { height } \\
\text { (cm) }\end{array}$ & $\begin{array}{c}\text { Head } \\
\text { Diameter } \\
(\mathbf{c m})\end{array}$ & $\begin{array}{c}\text { No of } \\
\text { branches / } \\
\text { plant }\end{array}$ & $\begin{array}{l}\text { Seed } \\
\text { filling } \\
(\%)\end{array}$ & $\begin{array}{c}\text { Hull } \\
\text { content } \\
(\%)\end{array}$ & $\begin{array}{c}100 \text { seed } \\
\text { weight } \\
(\mathrm{g})\end{array}$ & $\begin{array}{c}\text { Oil } \\
\text { content } \\
(\%)\end{array}$ & $\begin{array}{c}\text { Pollen } \\
\text { production } \\
\text { (mg) / plant }\end{array}$ & $\begin{array}{l}\text { Volume } \\
\text { weight } \\
\text { (g)/ } \\
\text { plant }\end{array}$ & $\begin{array}{l}\text { Seed } \\
\text { yield } \\
\text { (g)/ } \\
\text { plant }\end{array}$ \\
\hline 1. & Cluster I & 58.47 & 97.51 & 127.28 & 13.47 & 4.41 & 68.37 & 29.85 & 3.69 & 32.27 & 356.91 & 52.97 & 31.27 \\
\hline 2. & Cluster II & 57.88 & 99.38 & 113.63 & 12.69 & 4.96 & 66.13 & 30.63 & 3.48 & 27.11 & 337.63 & 55.15 & 36.32 \\
\hline 3. & Cluster III & 61.5 & 103.00 & 156.5 & 22.00 & 2.45 & 74.50 & 29.0 & 3.44 & 29.80 & 429.00 & 64.00 & 38.50 \\
\hline 4. & Cluster IV & 59.00 & 100.5 & 157.00 & 12.0 & 7.15 & 68.0 & 29.00 & 4.93 & 31.30 & 304.50 & 55.54 & 29.6 \\
\hline 5. & Cluster V & 56.50 & 98.50 & 150.50 & 17.38 & 6.80 & 73.0 & 28.50 & 4.07 & 35.55 & 354.00 & 52.30 & 29.95 \\
\hline 6. & Cluster VI & 55.50 & 104.00 & 158.0 & 21.50 & 1.80 & 70.00 & 30.00 & 4.80 & 32.76 & 396.00 & 45.95 & 27.16 \\
\hline 7. & Cluster VII & 55.50 & 88.00 & 177.00 & 18.00 & 0.00 & 77.0 & 27.5 & 6.15 & 35.95 & 519.50 & 52.90 & 32.00 \\
\hline
\end{tabular}


Hence crosses can be made between the genotypes of these clusters during hybridization programme for obtaining superior hybrids.

\section{References}

Ananda kumar, B. V., Parameshwarappa, K. G. and Lingaraju, B. S. 2008. Genetic divergence in parental and inbred lines of sunflower. (Helianthus annuus L.) Karnataka J. Agric. Sci., 21 (3): 339342.

Anonymous, (2017-2018), Directors report, AICRP on sunflower ICAR-Indian Institute of Oilseeds Research, Hyderabad pp-14-15.

Chandirakala, R. and Manivannan, N. 2014. Genetic diversity among sunflower genotypes. Electronic journal of plant breeding. 5(3): 577-580.

Dan, G., Manivannan, N. and Vindhiyavarman, P. 2012. Genetic diversity in sunflower (Helianthus annuus L.). E. Journal of Plant Breeding. 3(1): 652-656.

Dhillon, S. K., Chandra P. and Tyagi V. 2017. Assessment of phenotypic divergence and association studies in Sunflower (Helianthus annuus L.). $J$ Krishi Vigyan. 5(2): 8-14.

Sanju, Kamble, K. R., Pole, S. P. and Bhikane M. U. 2018. Genetic Divergence Analysis in Sunflower (Helianthus annuus L.) Restorer Lines. Int.J.Curr. Microbiol.App.Sci. (6): 742-749

Shamshad, M., Dhillon, S. K., Tyagi, V. and Akhatar, J. 2014. Assessment of Genetic Diversity in Sunflower (Helianthus annuus L.) Germplasm. International Journal of Agriculture and Food Science Technology. 5 (4): 267-272

Sujatha, H. L., Chikkadevaiah and Nandini. 2002. Assessment of genetic diversity among 51 inbred sunflower lines. Helia, 25 (37):101-108.

\section{How to cite this article:}

Naik, G.H., M.K. Ghodke and Chavan, T.A. 2018. Genetic Diversity Analysis in Multihead Inbred Lines of Sunflower (Helianthus annuus L.). Int.J.Curr.Microbiol.App.Sci. 7(10): 324329. doi: https://doi.org/10.20546/ijcmas.2018.710.034 